\title{
The effect of process conditions on the flocculation process occurring in an agitated vessel
}

\author{
Radek Šulc, Pavel Ditl \\ Czech Technical University in Prague, Faculty of Mechanical Engineering, Department of Process Engineering, \\ Technická 4, 16607 Prague, Czech Republic \\ "Corresponding author: Radek.Sulc@fs.cvut.cz
}

\begin{abstract}
The effect of flocculation time, flocculant dosage, pollutant concentration, mixing intensity and tank size on flocculation performance was experimentally studied in a mechanically agitated vessel. The macroscopic approach was applied for flocculation modelling. The simple semi-empirical generalized correlation for flocculation kinetics proposed by Šulc (2003a) and the simple semi-empirical generalized correlation quantifying the effect of flocculation time and flocculant dosage on flocculation proposed by Šulc, Ditl (2007) were used for data treatment.
\end{abstract}

Keywords: flocculation, flocculation kinetics, mixing, Rushton turbine, flocculant dosage, scale up.

\section{INTRODUCTION}

Flocculation has very important application in solid liquid separation processes, and in water supply and wastewater treatment. The primary purpose of flocculation is to transform smaller particles into larger aggregates flocs that will eventually settle so that efficient separation is achieved. The first step in the flocculation process is a chemical interaction among the added flocculant, the water and the suspended colloidal solids. The second step is to aggregate the destabilized particles into flocs. The first phase is considered to be completed within a few seconds, whereas the second phase may continue for minutes or hours. During flocculation, the mixing of a suspension causes collisions between the particles and the formation of flocs. This brings about the growth of particle aggregates of such size and consistency that effective separation can take place. Increased mixing promotes floc collisions, and in this way their formation and growth are accelerated. However, if the agitation is too intensive, the turbulent shear forces can break the flocs down into smaller particles again. This breakage decreases the separation efficiency. Then, in order to achieve the required separation efficiency, the flocculation agent dosage has to be increased. Flocculation agents are expensive, and the dosage depends on flocculant type, preparation and mixing conditions.

Thomas et al. ${ }^{1}$ classified published flocculation models according to modelling approach into the following groups: 1) modelling based on a microscopic approach,

2) modelling based on a macroscopic approach and

3) modelling based on a thermodynamic approach. Modelling based on a microscopic approach is based on the description of microscopic phenomena such as interparticle collisions, particle concentration and flocculation rate. These models can be further classified into models based on Smoluchowski ${ }^{2}$ approach and models based on population balance. However, processes such as precipitation, destabilisation and surface adsorption can be affected by the surface chemistry. According to Thomas et al. ${ }^{1}$ the models either ignore the surface chemical effects or dealt with them in a simplified form. The experimental results have often been obtained for idealised artificial particle suspensions such as suspensions of uniform latex spheres. In real systems the presence of other soluble chemicals, e.g. such as alkalinity, hardness phosphate and humic compounds, complicates modelling. Unfortunately the interactions among these chemicals, the flocculant and primary particles are complex and poorly known. It could therefore be difficult to determine the mutual dependence between the process parameters such as mixing time and intensity, on the one hand, and flocculant dosage and flocculation kinetics, on the other. In addition, flocculation models adopting the Smoluchowski equation are limited by the constraints imposed by Smoluchowski's six principal assumptions and the population balance models have often been conditional on the floc size being less than Kolmogoroff length microscale. The macroscopic approach is a compromise between microscopic phenomena modelling and empirical measurements. For this approach, Thomas et al. ${ }^{1}$ proposed that it is necessary to know the relation between macroscopic scales of flocculation, e.g. fractal dimension, and process parameters.

We adopted the macroscopic approach, which is a compromise between the microscopic phenomena modelling and the empirical measurements, and we focused our attention on finding the interrelation between macroscopic scale and process parameters. This paper presents a summary of our results obtained during a long-term research. The effect of flocculation time, flocculant dosage, impurity concentration, mixing intensity and tank size on flocculation performance will be presented here.

\section{EXPERIMENTS}

The flocculation experiments were conducted in a fully baffled cylindrical vessel of diameter $\mathrm{D}=150 \mathrm{~mm}$, filled to height $\mathrm{H}=\mathrm{D}$ with a model wastewater. The vessel was usually agitated by a Rushton turbine. A 6-pitched blade turbine was used in some of the experiments. The impeller of the diameter $\mathrm{d}=60 \mathrm{~mm}$ was placed at an off-bottom clearance of $\mathrm{H}_{2} / \mathrm{d}=0.85 \mathrm{~mm}$. The impeller speed was set up and the impeller power input value was calculated using the impeller power characteristics.

The flocs were separated by sedimentation. After the sedimentation running for 5 minutes (for sedimentation velocity $u_{\text {sed }}=0.03 \mathrm{~m} / \mathrm{min}$ and given geometry) the clarified water sample was withdrawn. The sampling point was located at the level of the upper impeller edge. The 
turbidity of the clarified water sample was measured using MultiLab5 (WTW, Germany). The built-in photometer measured the turbidity using the reference ray method. The aqueous suspension of amorphous $\mathrm{SiO}_{2}$, clay and kaolin, respectively, was used as a model wastewater.

\section{EXPERIMENTAL RESULTS}

\section{Flocculation kinetics}

The turbidity is commonly used in practice as a measure of solid pollutant content. Thus flocculation efficiency is frequently defined as the rate of turbidity removal:

$Z_{e}^{*}\left(t_{F}\right)=\frac{Z_{e}\left(t_{F}\right)}{Z_{0}}=\frac{Z_{0}-Z_{r}\left(t_{F}\right)}{Z_{0}}=1-Z_{r}^{*}\left(t_{F}\right)$

where $\mathrm{Z}_{\mathrm{e}}{ }^{*}$ is the degree of turbidity removal, $\mathrm{Z}_{\mathrm{r}}{ }^{*}$ is the degree of residual turbidity, $Z_{0}$ is the turbidity of the suspension before the beginning of flocculation, $Z_{\mathrm{e}}$ is the eliminated turbidity due to flocculation, $Z_{r}$ is the residual turbidity of the clarified water after floc separation, and $\mathrm{t}_{\mathrm{F}}$ is the flocculation time.

The effect of the flocculant dosage on the flocculation kinetics of kaolin slurry was investigated ${ }^{3}$ in a baffled tank agitated by a Rushton turbine at mixing intensity $168 \mathrm{~W} / \mathrm{m}^{3}$ (corresponding impeller speed $\mathrm{N}=290 \mathrm{rev} /$ min) and kaolin concentration $0.58 \mathrm{~g} / \mathrm{l}$. The flocs were separated by 5 -minute sedimentation. The tests were carried out on a model wastewater (a slurry of tap water and kaolin). The model wastewater was flocculated using Sokoflok 16A organic flocculant (solution 0.1\% wt.; Sokoflok Ltd. Czech Republic). The experimental data are presented in Fig. 1. With increasing flocculation time, the degree of turbidity removal increases at the given flocculant dosage for $t_{F} \leq 10 \mathrm{~min}$. For $t_{F}>10 \mathrm{~min}$, the degree of turbidity removal decreases slightly due to the floc breakage. Maximum turbidity removal $97.6 \%$ was observed at flocculation time $10 \mathrm{~min}$ and at flocculant dosage $2 \mathrm{ml} / \mathrm{l}$. The simple semiempirical generalized correlation for flocculation kinetics proposed by Šulc ${ }^{4}$ and the simple semiempirical generalized correlation quantifying the effect of flocculation time and flocculant dosage on flocculation (see below) proposed by Šulc, Ditl $^{5}$ were used for data treatment.

The following generalized correlation for flocculation kinetics in an agitated tank, taking into account floc breakage was proposed ${ }^{4}$ :

$\Delta Z_{r}^{*}=A_{Z r^{*}}^{*} \cdot\left(\Delta\left[N \cdot t_{F}\right]_{\log }^{*}\right)^{2}$

where

$\Delta Z_{r}^{*}=\frac{Z_{r}^{*}-Z_{r_{\min }}^{*}}{Z_{r_{\min }}^{*}}$

$\Delta\left[N \cdot t_{F}\right]_{\log }^{*}=\frac{\log \left(N \cdot t_{F}\right)-\log \left(\left[N \cdot t_{F}\right]_{\min }\right)}{\log \left(\left[N \cdot t_{F}\right]_{\min }\right)}$,

where $Z_{r \text { min }}^{*}$ is the minimum degree of residual turbidity achieved at time $\left[N . t_{F}\right]_{\min },\left[N . t_{F}\right]_{\min }$ is the dimensionless flocculation time in which $\mathrm{Z}_{\mathrm{r} \text { min }}{ }^{*}$ can be achieved, $\mathrm{A}_{\mathrm{Zr}^{*}}{ }^{*}$ is the residual turbidity shift coefficient, $t_{F}$ is flocculation time, and $\mathrm{N}$ is impeller rotational speed. The residual turbidity shift coefficient parameter $\mathrm{A}_{\mathrm{Zr}^{*}}{ }^{*}$ is a measure of flocculation rate. In our case, a higher value of $\mathrm{A}_{\mathrm{Zr}^{*}}{ }^{*}$ means a faster decrease of turbidity up to a minimum that is characterized by $\left[\mathrm{N} . \mathrm{t}_{\mathrm{F}}\right]_{\min }$ and $\mathrm{Z}_{\mathrm{r} \min }^{*}$. A higher value of $\mathrm{A}_{\mathrm{Zr}^{*}}{ }^{*}$ indicates a faster increase in turbidity above the minimum due to floc breakage.

The generalized correlation parameters $\mathrm{Z}_{\mathrm{r} \min }^{*}$, [N.t $\left.\mathrm{t}_{\mathrm{F}}\right]$ min and $\mathrm{A}_{\mathrm{Zr}^{*}}{ }^{*}$ generally depend on the flocculation process conditions, i.e. mixing intensity, flocculant dosage. The correlation proposed here allows us to determine the flocculation time at which the minimum degree of residual turbidity and the maximum degree of turbidity removal, respectively, can be achieved. A comparison between the experimental data and the generalized correlation is shown in Fig. 2. The similar results were also obtained for amorphous $\mathrm{SiO}_{2}$ and clay ${ }^{5,17,23}$.

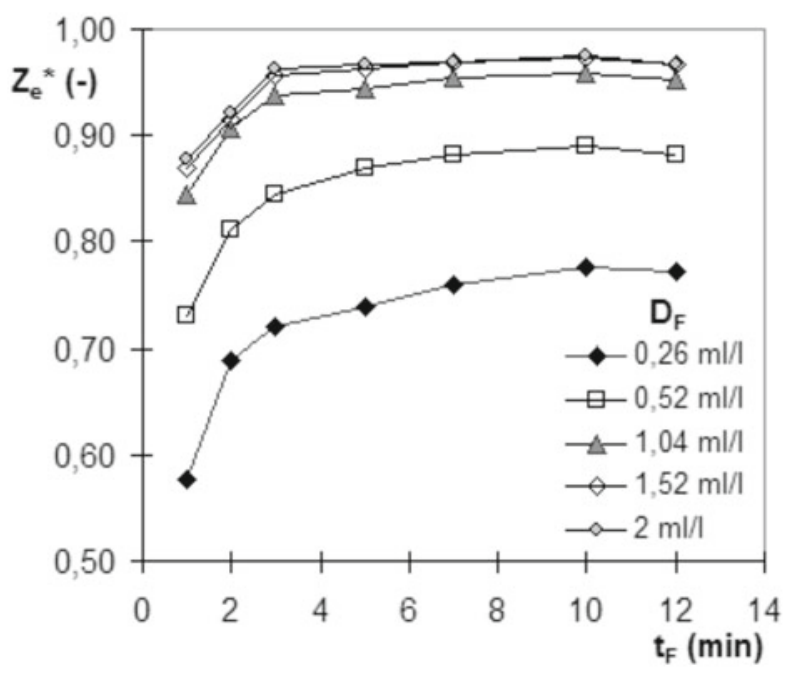

Figure 1. Experimental data $\mathrm{Z}_{\mathrm{e}}{ }^{*}=\mathrm{f}\left(\mathrm{t}_{\mathrm{F}}\right)$ for $\mathrm{D}_{\mathrm{F}}=$ const. - Sulc and Ditl ${ }^{3}$, kaolin, $\mathrm{c}_{\mathrm{K} 0}=0.58 \mathrm{~g} / \mathrm{l}, \varepsilon_{\mathrm{V}}=168 \mathrm{~W} / \mathrm{m}^{3}$

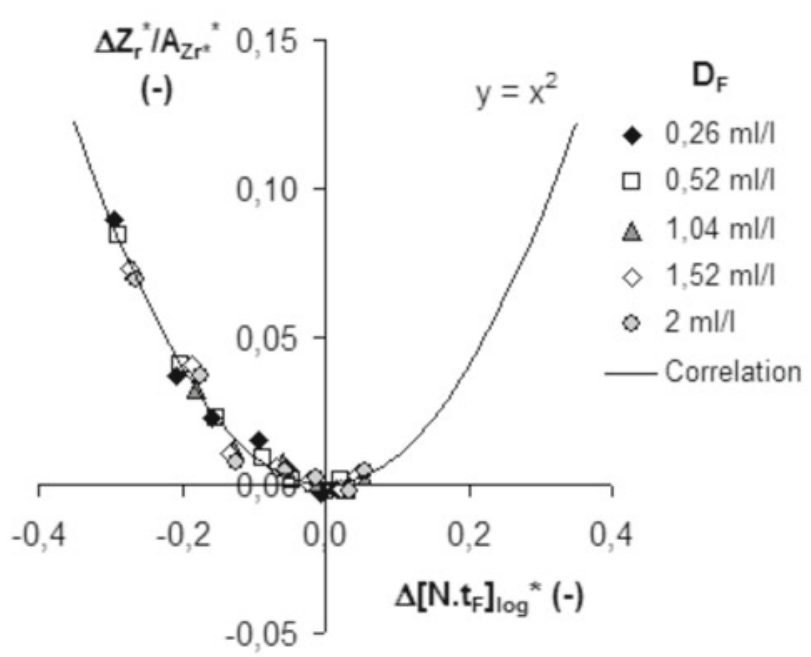

Figure 2. Experimental data vs. correlation (2) $\Delta Z_{r}{ }^{*}=f(\Delta[N$. $\left.\mathrm{t}_{\mathrm{F}}\right]^{*}{ }_{\log }$ ) for $\mathrm{D}_{\mathrm{F}}=$ const. - Sulc and Ditl ${ }^{3}$, kaolin, $\mathrm{c}_{\mathrm{K} 0}$ $=0.58 \mathrm{~g} / \mathrm{l}, \varepsilon_{\mathrm{V}}=168 \mathrm{~W} / \mathrm{m}^{3}$

In Environmental Engineering, the flocculation performances occurring at various process conditions (impeller speed, mixing intensity, tank size) have been compared in the same flocculation time $t_{\mathrm{F}}$. However, this comparison is correct only for the processes occurring in vessels of the same size, and for the same impeller speed. Both particle collisions and floc size reduction occur mainly in the impeller zone, where the turbulent energy dissipation rate is maximal. Therefore the effect of the number of 
floc passages through the impeller zone on the flocculation course can be expected and should be taken into account. The number of passages through the impeller zone is proportional to the circulation time. Similarly, aggregation occurs during fluid circulation in a vessel, so it is also proportional to the circulation time. As the vessel size increases, the circulation time increases strongly. A similar effect of circulation time was also observed in a liquid - liquid dispersion process occurring in stirred vessels. The circulation time is indirectly proportional to the impeller rotational speed. This implies that dimensional flocculation time, which is proportional to the number of floc passages through an impeller zone, must be defined as the product of impeller speed $\mathrm{N}$ and flocculation time $t_{\mathrm{F}}$. The dimensionless flocculation time defined as the product N.t $\mathrm{F}_{\mathrm{F}}$ has therefore been used as a scale of flocculation time. This phenomenon is crucial for process scale-up.

The proposed general correlation was tested on the experimental data published in Bernhardt, Schell ${ }^{6}$. Bernhardt, Schell $^{6}$ investigated the effect of mixing intensity on flocculation kinetics of the model suspension of quartz particles (Sikron F100) flocculated by $\mathrm{Fe}^{3+}$ inorganic flocculant in a tank stirred by a two-paddle stirrer. The tests were carried out at a constant particle concentration. The flocs were separated by a filtration. The dependence of residual turbidity in a filtrate on the flocculation time at different mixing intensity was measured. The mixing intensity was characterized by the velocity gradient $G$, defined as $\left.\mathrm{G}=((\mathrm{P} / \mathrm{V}) / \mu)^{1 / 2}=\left(\varepsilon_{\mathrm{V}}\right) / \mu\right)^{1 / 2}$. For $\mathrm{G}=16$, 30 and $40 \mathrm{~s}^{-1}$ (i.e. $\varepsilon_{\mathrm{V}}=0.26,0.9$ and $1.6 \mathrm{~W} / \mathrm{m}^{3}$ ), no floc breakage was observed. In the remaining G-range of 50 $\div 150 \mathrm{~s}^{-1}$ (i.e. $\varepsilon_{\mathrm{V}}=2.5 \div 22.5 \mathrm{~W} / \mathrm{m}^{3}$ ) floc breakage was observed. No flocculation model was applied for data interpretation. A comparison between the experimental data and the generalized correlation is shown in Fig. 3. The relations $\mathrm{A}_{\mathrm{Zr}^{*}}^{*}=43.529 . \varepsilon_{\mathrm{V}}^{-0.766}\left(\mathrm{R}^{2}=0.9357\right), \mathrm{Z}_{\mathrm{r} \text { min }}^{*}$ $=0.1386 . \varepsilon_{\mathrm{V}}{ }^{0.425}\left(\mathrm{R}^{2}=0.9703\right)$ and $\left[\mathrm{N} . \mathrm{t}_{\mathrm{F}}\right]_{\min }=2182.9 . \varepsilon_{\mathrm{V}}$ ${ }^{0.825}\left(\mathrm{R}^{2}=0.9832\right)$ were found for the model parameters.

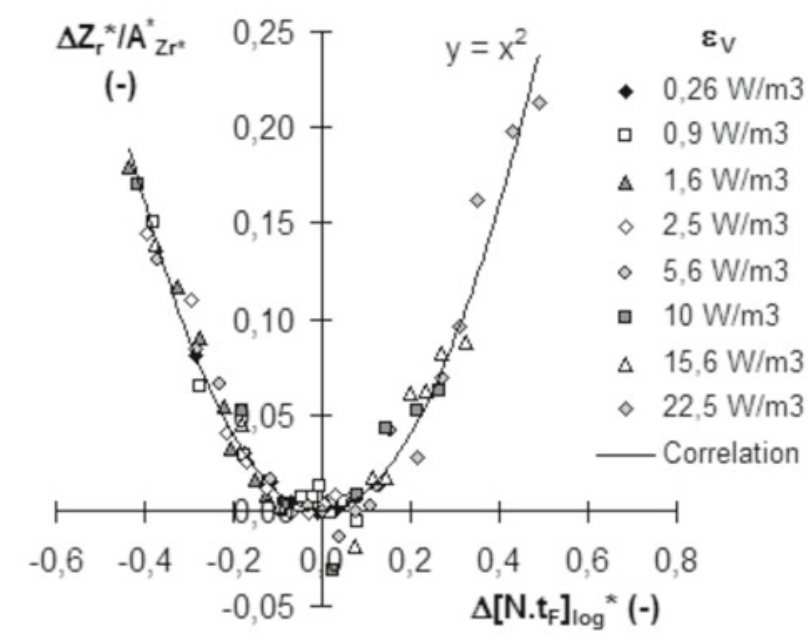

Figure 3. Experimental data vs. correlation (2) $\Delta \mathrm{Z}_{\mathrm{r}}^{*}=\mathrm{f}(\Delta[\mathrm{N}$. $\left.\mathrm{t}_{\mathrm{F}}\right]^{*}{ }_{\log }$ ) for $\varepsilon_{\mathrm{V}}=$ const. - Bernhardt and Schell ${ }^{6}$, quartz, $\mathrm{c}_{\mathrm{q} 0}=0.025 \mathrm{~g} / \mathrm{l}, \mathrm{D}_{\mathrm{F}}=2.48 \mathrm{ml} / \mathrm{l}$

\section{Camp number}

The Camp number, defined as the product of velocity gradient $\mathrm{G}$ characterizing mixing intensity and floccula- tion time $\mathrm{t}_{\mathrm{F}}$, i.e. $\mathrm{Ca}=\mathrm{G} . \mathrm{t}_{\mathrm{F}}$, proposed by $\mathrm{Camp}^{7}$ postulates that same flocculation performance can be achieved at various velocity gradients at flocculation time satisfying relation G.t $\mathrm{F}_{\mathrm{F}}=$ const. Although the concepts of velocity gradient and Camp number have been criticized ${ }^{8-13}$, they can be still used for flocculation process design ${ }^{\text {14-16. }}$.

The effect of mixing intensity on the flocculation kinetics of amorphous $\mathrm{SiO}_{2}$ slurry was investigated ${ }^{17}$ in a baffled tank agitated by a Rushton turbine for various mixing intensities ranging from 40 to $520 \mathrm{~W} / \mathrm{m}^{3}$ at $\mathrm{SiO}_{2}$ concentration $0.8 \mathrm{~g} / \mathrm{l}$ and flocculant dosage $\mathrm{D}_{\mathrm{F}}=2.48$ $\mathrm{ml} / \mathrm{l}$. The floc breakage was observed in the whole measured mixing intensity range. The model wastewater was flocculated using Sokoflok 56A organic flocculant (solution 0.1\% wt.; Sokoflok Ltd. Czech Republic). The experimental data is presented in Fig. 4, and a comparison of the experimental data and the generalized correlation (2) is presented in Fig 5. The parabolic curve according to the correlation (2) depicted in Fig. 4 does not mean that the floc formation and the floc breakage are related in symmetrical manner. The asymmetry between the floc formation and their breakage is masked by the statistical treatment leading to the generalization and nonlinearities of $\mathrm{x}$ - and $\mathrm{y}$ - axes ${ }^{4}$.

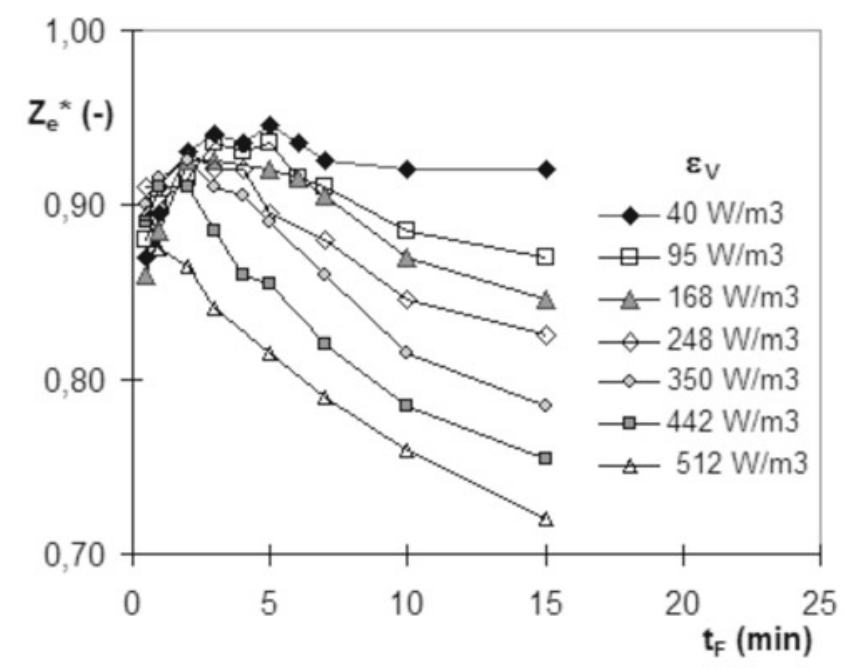

Figure 4. Experimental data $\mathrm{Z}_{\mathrm{e}}{ }^{*}=\mathrm{f}\left(\mathrm{t}_{\mathrm{F}}\right)$ for $\varepsilon_{\mathrm{V}}=$ const. - Sulc and $\mathrm{Ditl}^{17}, \mathrm{SiO}_{2}, \mathrm{c}_{\mathrm{S} 0}=0.8 \mathrm{~g} / \mathrm{l}, \mathrm{D}_{\mathrm{F}}=2.48 \mathrm{ml} / \mathrm{l}$

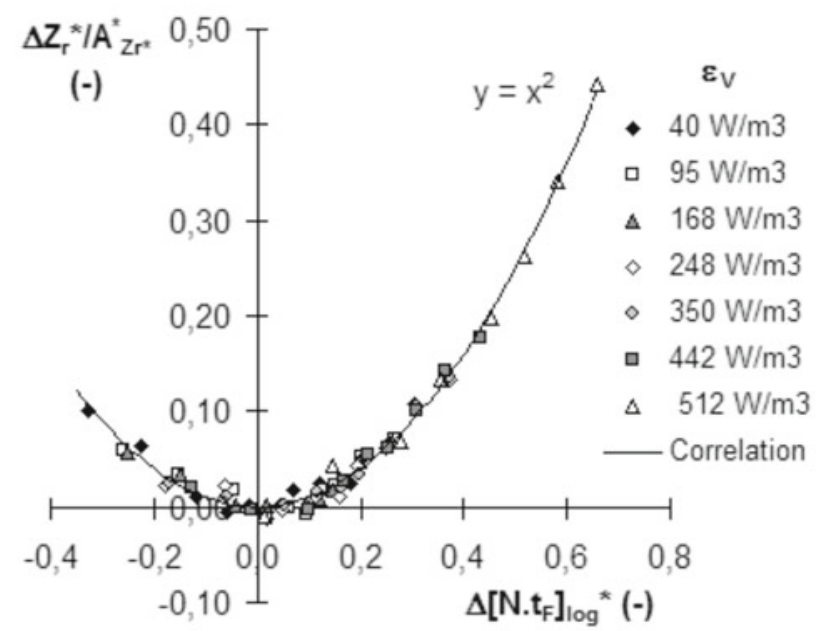

Figure 5. Experimental data vs. correlation (2) $\Delta \mathrm{Z}_{\mathrm{r}}^{*}=\mathrm{f}(\Delta[\mathrm{N}$. $\left.\left.\mathrm{t}_{\mathrm{F}}\right]^{*} \log \right)$ for $\varepsilon_{\mathrm{V}}=$ const. - Sulc and $\mathrm{Ditl}^{17}, \mathrm{SiO}_{2}, \mathrm{c}_{\mathrm{S} 0}$ $=0.8 \mathrm{~g} / \mathrm{l}, \mathrm{D}_{\mathrm{F}}=2.48 \mathrm{ml} / \mathrm{l}$ 
Table 1. Camp number calculated for given turbidity removal degree

\begin{tabular}{|c|c|c|c|c|}
\hline \multicolumn{5}{|c|}{ Data: Šulc and Ditl ${ }^{17}, \mathrm{SiO}_{2}, \mathrm{C}_{\mathrm{S} 0}=0.8 \mathrm{~g} / \mathrm{l}, \mathrm{D}_{\mathrm{F}}=2.48 \mathrm{ml} / \mathrm{l}$} \\
\hline$\varepsilon_{\mathrm{V}}$ & $G$ & \multicolumn{3}{|c|}{$\mathrm{Ca}=\mathrm{G} \cdot \mathrm{t}_{\mathrm{F}}(-)$} \\
\hline$\left(\mathrm{W} \cdot \mathrm{m}^{-3}\right)$ & $\left(s^{-1}\right)$ & $Z_{e}^{*}=0.90$ & $Z_{e}{ }^{*}=0.91$ & $Z_{e}{ }^{*}=0.92$ \\
\hline 40 & 200 & 10852 & 13856 & 18253 \\
\hline 95 & 309 & 14707 & 18577 & 25043 \\
\hline 168 & 410 & 24226 & 30151 & 40795 \\
\hline 248 & 498 & 13927 & 17672 & 23704 \\
\hline 250 & 592 & 19038 & 23120 & 31179 \\
\hline 442 & 665 & 23632 & * & * \\
\hline 512 & 716 & * & * & * \\
\hline \multicolumn{5}{|c|}{ Data: Bernhardt and Schell ${ }^{6}$, quartz, $\mathrm{C}_{\mathrm{q} 0}=0.025 \mathrm{~g} / \mathrm{l}, \mathrm{D}_{\mathrm{F}}=2.48 \mathrm{ml} / \mathrm{l}$} \\
\hline$\varepsilon_{\mathrm{V}}$ & G & \multicolumn{3}{|c|}{$\mathrm{Ca}=\mathrm{G} \cdot \mathrm{t}_{\mathrm{F}}(-)$} \\
\hline$\left(\mathrm{W} \cdot \mathrm{m}^{-3}\right)$ & $\left(\mathrm{s}^{-1}\right)$ & $Z_{e}^{*}=0.60$ & $Z_{e}^{*}=0.70$ & $Z_{e}^{*}=0.80$ \\
\hline 1.6 & 40 & 11700 & 19625 & 45341 \\
\hline 2.5 & 50 & 13792 & 21655 & 48196 \\
\hline 5.63 & 75 & 13041 & 26257 & * \\
\hline 10 & 100 & 18592 & * & * \\
\hline 15.6 & 125 & * & * & * \\
\hline 22.5 & 150 & * & * & * \\
\hline
\end{tabular}

Notice: * A given turbidity removal degree is not reachable at given conditions.

Table 1 illustrates the limited applicability of the generally used designing procedure based on the constant Camp number value. For a given turbidity removal degree, i.e. a given flocculation performance, the corresponding flocculation time was calculated for various mixing intensities using the correlation (2) for our data and also for the data published by Bernhardt, Schell ${ }^{6}$. Consequently, the Camp number values were calculated. From Table 1 it follows that the same flocculation efficiency $\left(\mathrm{Z}_{\mathrm{e}}{ }^{*}=\right.$ $90 \%$ or $75 \%$ ) can not be reached at the constant Camp number value.

\section{Static mixer}

It was found $\mathrm{d}^{4}$ that the proposed generalized correlation (2) can be extended up to flocculation effected by a static mixer adopting dimensionless flocculation time equal to the number of elements $i_{S}$ that a static mixer consists of: $t_{F}^{*}=\frac{t_{M}}{t_{M_{1}}}=\frac{l_{S}}{l_{E}}=i_{S}$

where $t_{M}$ is the mean mixing time in a static mixer, $t_{M 1}$ is the mean mixing time in a static mixer element, $l_{S}$ is static mixer length and $l_{\mathrm{E}}$ is element length. The dimensionless flocculation time defined in this way is analogous to the dimensionless time defined for an agitated vessel.

Thus, the generalized correlation is given as follows: $\Delta Z_{r}^{*}=A_{Z r^{*}}^{*} \cdot\left(\Delta\left[i_{S}\right]_{\log }^{*}\right)^{2}$

where

$\Delta Z_{r}^{*}=\frac{Z_{r}^{*}-Z_{r_{\text {min }}}^{*}}{Z_{r_{\text {min }}}^{*}}$

where $\left[\mathrm{i}_{\mathrm{S}}\right]_{\min }$ corresponds to the number of static mixer elements in which $Z_{\mathrm{r} \text { min }}^{*}$ can be achieved.

The proposed model was successfully tested ${ }^{18}$ on the data reported by Suharyono, Hogg ${ }^{19}$. Suharyono, $\operatorname{Hogg}^{19}$ performed a laboratory investigation of flocculation following the addition of an organic polymer flocculant to kaolin clay slurries flowing through static mixers (Kenics). The flocculation performance was evaluated according to the settling rate and the supernatant turbidity. The effect of the mixing time was controlled by the number of mixer elements in a pipe. The mixing intensity was varied according to the suspension flowrate. A comparison of the experimental data and the proposed generalized correlation (6) is depicted in Fig. 6. The specific power input was estimated using the Darcy-Weisbach equation.

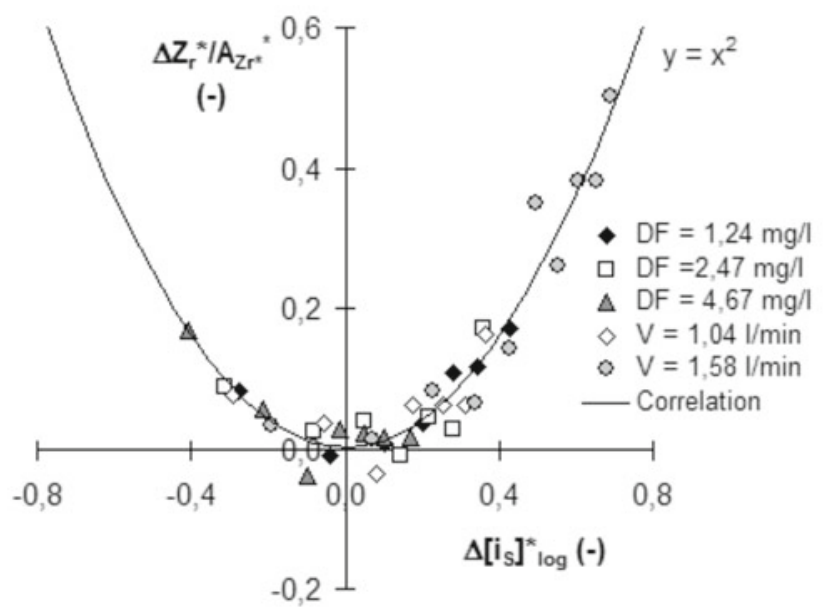

Figure 6. Experimental data vs. correlation (6) $\Delta \mathrm{Z}_{\mathrm{r}}^{*}=\mathrm{f}$ $\left(\Delta\left[\mathrm{i}_{\mathrm{S}}\right]_{\log }{ }_{\log }\right)$ - data Suharyono and $\mathrm{Hogg}^{19}$

\section{Effect of the flocculant dosage}

The effect of flocculant dosage on flocculation was investigated $\mathrm{d}^{20}$ in our laboratory using a baffled tank agitated by a Rushton turbine and a 6-pitched blade turbine at constant mixing intensity $\varepsilon_{\mathrm{V}}=40 \mathrm{~W} / \mathrm{m}^{3}$. The flocs were separated by sedimentation. The tests were carried out on a model wastewater (a suspension of tap 
water $+\mathrm{SiO}_{2}$; constant particle concentration $800 \mathrm{mg} / \mathrm{l}$ ). The model wastewater was flocculated with Sokoflok 56A organic flocculant (solution $0.1 \%$ wt.; Sokoflok Ltd., Czech Republic) at $\mathrm{pH}$ 7.6.

A simple semi-empirical generalized correlation quantifying the effect of flocculant dosage on flocculation was proposed:

$$
\Delta Z_{r}^{*}=A_{Z r^{*}(D)}^{*} \cdot\left(\Delta\left[D_{F}\right]_{\log }^{*}\right)^{2}
$$

where

$$
\begin{aligned}
& \Delta Z_{r}^{*}=\frac{Z_{r}^{*}-Z_{r_{\min (D)}}^{*}}{Z_{r_{\min (D)}^{*}}^{*}} \\
& \Delta\left[D_{F}\right]_{\log }^{*}=\frac{\log \left(D_{F}\right)-\log \left(D_{F \min }\right)}{\log \left(D_{F \min }\right)}
\end{aligned}
$$

where $\mathrm{Z}_{\mathrm{r} \min }^{*}$ is the minimal degree of residual turbidity achieved at flocculant dosage $\mathrm{D}_{\mathrm{Fmin}}, \mathrm{D}_{\mathrm{Fmin}}$ is the flocculant dosage for which $\mathrm{Z}_{\mathrm{r} \text { min }}^{*}$ can be achieved, and $\mathrm{A}_{\mathrm{Zr}(\mathrm{D})}^{*}$ is the residual turbidity shift coefficient.

The generalized correlation parameters $Z_{r \text { min }}^{*}, D_{\text {Fmin }}$ and $\mathrm{A}_{\mathrm{Zr}(\mathrm{D})}^{*}$ generally depend on the flocculation process conditions, e.g. mixing intensity, flocculation time. The proposed model was successfully tested on the experimental data that was obtained. The experimental data for a Rushton turbine are presented in Fig. 7. A comparison of the experimental data and the generalized correlation for a Rushton turbine is depicted in Fig. 8.

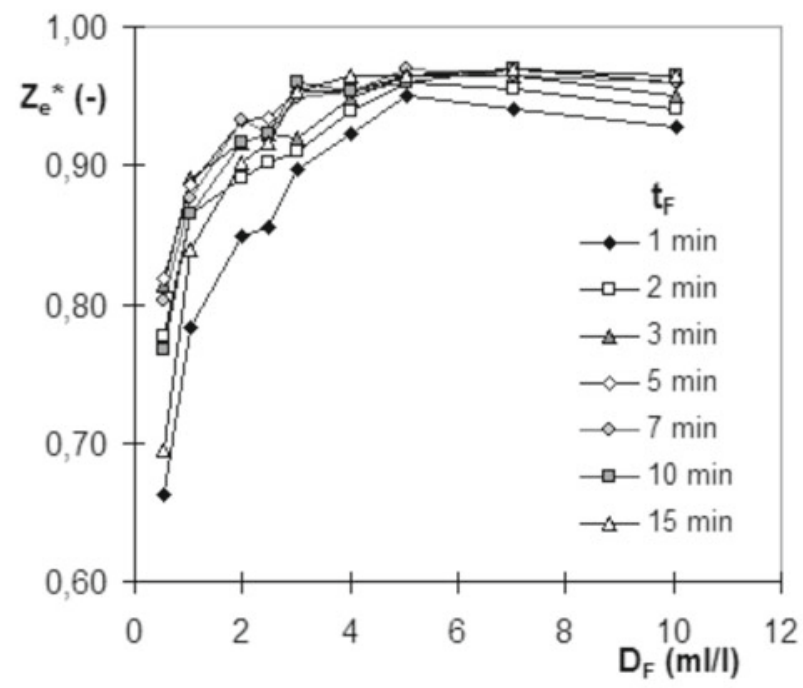

Figure 7. Experimental data $Z_{r}^{*}=f\left(D_{F}\right)$ for $t_{F}=$ const. - Sulc and $\mathrm{Ditl}^{20}, \mathrm{SiO}_{2}, \mathrm{c}_{\mathrm{S} 0}=0.8 \mathrm{~g} / \mathrm{l}, \varepsilon_{\mathrm{V}}=40 \mathrm{~W} / \mathrm{m}^{3}$

\section{Effect of flocculation time and flocculant dosage}

On the basis of our earlier results, we proposed ${ }^{5}$ the following simple semi-empirical generalized correlation quantifying the effect of flocculation time and the flocculant dosage on flocculation:

$$
\begin{aligned}
& \Delta Z_{r}^{*}=A_{12}^{*} \cdot\left(\Delta\left[N \cdot t_{F}\right]_{\log }^{*}\right)^{2}+A_{22}^{*} \cdot\left(\Delta\left[\frac{D_{F}}{c_{p 0}}\right]_{\log }^{*}\right)^{2}+ \\
& +B_{11}^{*} \cdot\left(\Delta\left[N \cdot t_{F}\right]_{\log }^{*}\right) \cdot\left(\Delta\left[\frac{D_{F}}{c_{p 0}}\right]_{\log }^{*}\right) \\
& \Delta Z_{r}^{*}=\frac{Z_{r}^{*}-Z_{r_{\min (t, D)}}^{*}}{Z_{r_{\min (t, D)}^{*}}}
\end{aligned}
$$

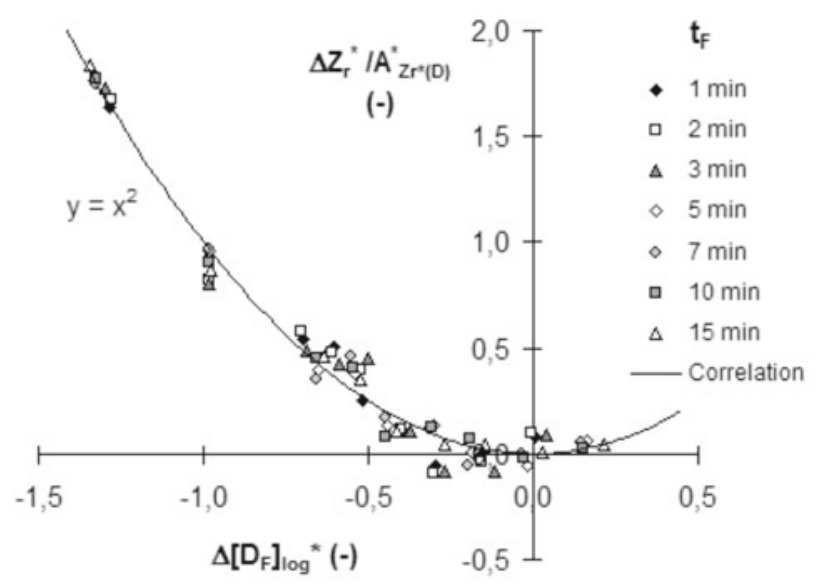

Figure 8. Experimental data vs. correlation (9) $\Delta \mathrm{Z}_{\mathrm{r}}^{*}=\mathrm{f}\left(\Delta\left[\mathrm{D}_{\mathrm{F}}\right]\right.$ $\left.{ }^{*}{ }^{*}\right)$
$\mathrm{W} / \mathrm{m}^{3}$

The ratio $\mathrm{D}_{\mathrm{F}} / \mathrm{c}_{\mathrm{p} 0}$ represents the dimensionless flocculant dosage defined as the ratio of flocculant dosage $\mathrm{D}_{\mathrm{F}}$ and the initial pollution concentration $\mathrm{c}_{\mathrm{p} 0}$. Parameter $\mathrm{Z}_{\mathrm{r} \min (\mathrm{t}, \mathrm{D})}^{*}$ and the corresponding parameters $\left[\mathrm{N} . \mathrm{t}_{\mathrm{F}}\right]_{\min }$ and $\left[\mathrm{D}_{\mathrm{F}} / \mathrm{c}_{\mathrm{p} 0}\right]_{\min }$ represent the optimal conditions under which minimum residual turbidity can be achieved. The coefficients $\mathrm{A}_{12}{ }^{*}, \mathrm{~A}_{22}{ }^{*}, \mathrm{~B}_{11}{ }^{*}$ are residual turbidity shift coefficients due to flocculation time, flocculant dosage, and miscellaneous effects of both variables, respectively. The model parameters generally depend on the mixing intensity. The proposed generalized correlation was tested on our data ${ }^{3}$. A comparison of the experimental data and the generalized correlation (12) is depicted in Fig. 9.

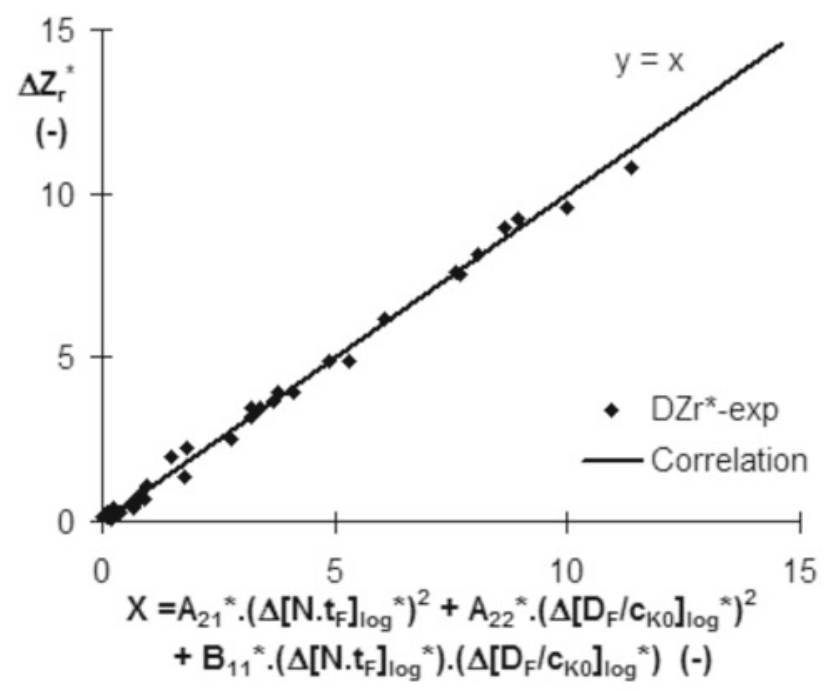

Figure 9. Experimental data vs. correlation (12) $\Delta \mathrm{Z}_{\mathrm{r}}^{*}=\mathrm{f}$ $\left(\Delta\left[\mathrm{N} . \mathrm{t}_{\mathrm{F}}\right]_{\log }^{*}, \Delta\left[\mathrm{D}_{\mathrm{F}} / \mathrm{c}_{\mathrm{K} 0}\right]_{\log }{ }^{*}\right)-$ Šulc and Ditl ${ }^{3}$, kaolin, $\mathrm{c}_{\mathrm{K} 0}=0.58 \mathrm{~g} / \mathrm{l}, \varepsilon_{\mathrm{V}}=168 \mathrm{~W} / \mathrm{m}^{3}, \mathrm{t}_{\mathrm{F}}=1-12 \mathrm{~min}, \mathrm{D}_{\mathrm{F}}$ $=0.26-2 \mathrm{ml} / \mathrm{l}$

An analytical description of the dependence of degree of residual turbidity $\mathrm{Z}_{\mathrm{r}}^{*}$ on the flocculant dosage $\mathrm{D}_{\mathrm{F}}$ and on flocculation time $t_{\mathrm{F}}$ enables us to calculate numerically the dependence of flocculant dosage $\mathrm{D}_{\mathrm{F}}$ on flocculation time $t_{F}$ for the desired flocculation efficiency, in this case for the desired degree of residual turbidity $\mathrm{Z}_{\mathrm{r}}{ }^{*}$ or degree of turbidity removal $\mathrm{Z}_{\mathrm{e}}{ }^{*}$. For illustration, the graph of calculated isolines $\mathrm{D}_{\mathrm{F}}=\mathrm{f}\left(\mathrm{t}_{\mathrm{F}}\right)$ for $\mathrm{Z}_{\mathrm{r}}{ }^{*}=$ const. for a suspension of amorphous $\mathrm{SiO}_{2}$ particles (constant particle concentration $800 \mathrm{mg} / \mathrm{l}$ ) agitated by a Rushton 
turbine at mixing intensity $40 \mathrm{~W} / \mathrm{m}^{3}$ is presented in Fig. 10 for $\mathrm{Z}_{\mathrm{r}}{ }^{*}=0.15,0.1,0.08,0.06,0.05,0.04,0.035$, i.e. for $\mathrm{Z}_{\mathrm{e}}^{*}=0.85,0.9,0.92,0.94 ; 0.95,0.96 ; 0.965$.

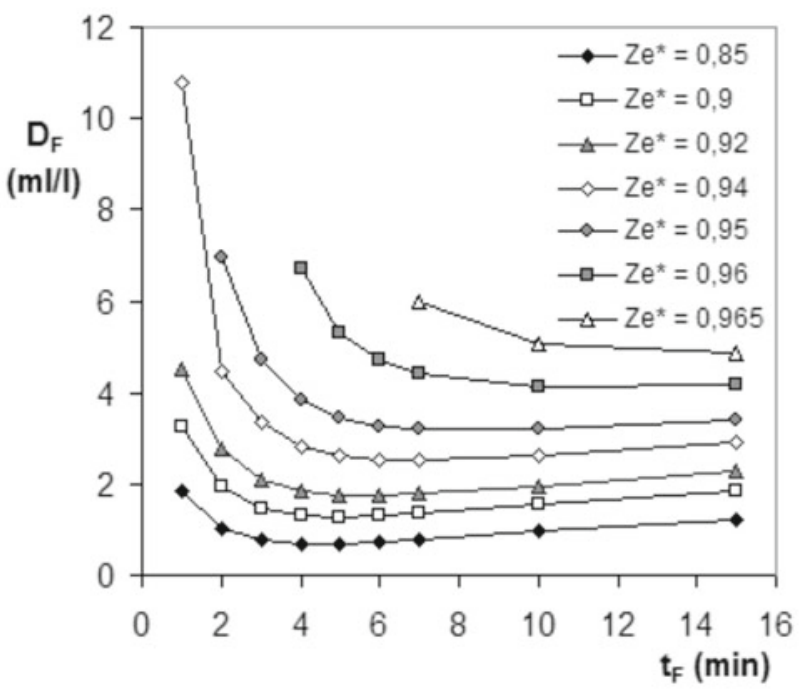

Figure 10. Isolines $D_{F}=f\left(t_{F}\right)$ for $Z_{r}^{*}=$ const. - data Šulc and $\mathrm{Ditl}^{20}, \mathrm{SiO}_{2}, \mathrm{c}_{\mathrm{S} 0}=0.8 \mathrm{~g} / \mathrm{l}, \varepsilon_{\mathrm{V}}=40 \mathrm{~W} / \mathrm{m}^{3}$

The graph $\mathrm{D}_{\mathrm{F}}=\mathrm{f}\left(\mathrm{t}_{\mathrm{F}}\right)$ for constant flocculation efficiency allows us to adjust the flocculant dosage according to the flocculation time, and vice versa, while the same flocculation efficiency is maintained. For example, flocculation occurs for 10 minutes and the flocculant dosage is $2 \mathrm{ml} / \mathrm{l}$. In our case, the degree of residual turbidity $8 \%$, i.e. degree of turbidity removal $92 \%$, is achieved for the given conditions. According to the graph, the same effect can be achieved for the same dosage after just three minutes.

For the batch system, in this way, the process duty can be increased by the reduction of the flocculation time at the same flocculant dosage at the same flocculation efficiency. Similarly, the same effect can be expected for a continuous system.

Our model and the proposed data treatment is applicable for different systems and it enables for each system turbidity removal degree prediction, determination of dependence of flocculant dosage $\mathrm{D}_{\mathrm{F}}$ on flocculation time $t_{F}$ for the desired flocculation efficiency and scale-up for a particular system. The adjustable model parameters should be determined for each system separately.

\section{Effect of pollutant concentration}

The effect of clay concentration on flocculation performance was investigated ${ }^{5}$ for various flocculant dosages and for three clay slurry concentration values at mixing intensity $\varepsilon=40 \mathrm{~W} / \mathrm{m}^{3}$. The flocculation experiments were conducted in a fully baffled cylindrical vessel of diameter $\mathrm{D}=150 \mathrm{~mm}$ agitated by a Rushton turbine. A water - clay particle suspension was used as a model system. The solid fraction of the clay was $0.48,0.58$ and $0.92 \mathrm{~g} / \mathrm{l}$, respectively. The model wastewater was flocculated using the Sokoflok 16A organic polymer flocculant (0.1\% wt. aqueous solution; Sokoflok Ltd. Czech Republic). The flocs were separated by the 5-minute sedimentation in the tank.

The fit tightness between the generalized correlation (12) and experimental data for the three different pollutant concentrations is depicted in Fig. 11. The systematic

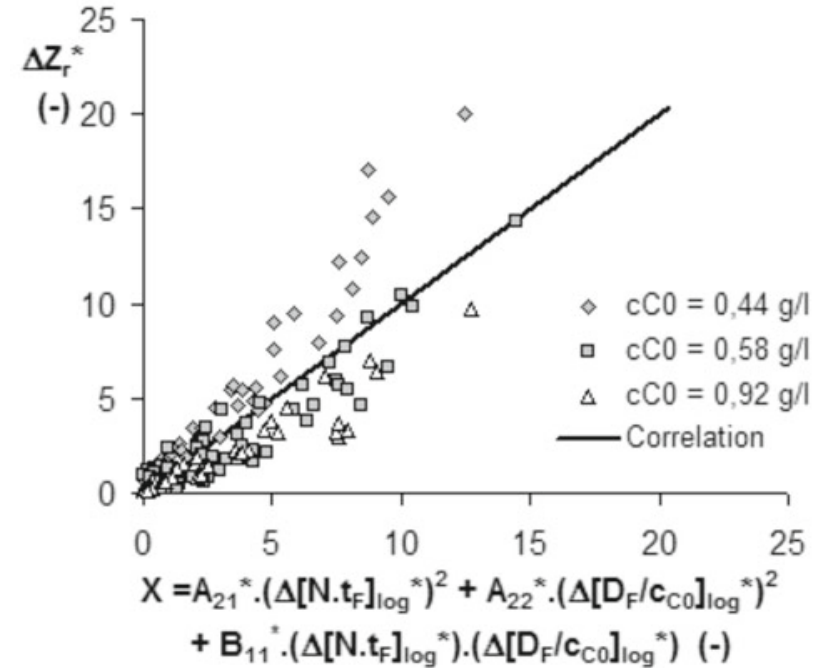

Figure 11. Experimental data vs. correlation (12) $\Delta \mathrm{Z}_{\mathrm{r}}^{*}=\mathrm{f}$ $\left(\Delta\left[\mathrm{N} . \mathrm{t}_{\mathrm{F}}\right]_{\log }^{*}, \Delta\left[\mathrm{D}_{\mathrm{F}} / \mathrm{c}_{\mathrm{C} 0}\right]_{\log }{ }^{*}\right)-$ Suulc and Ditl ${ }^{5}$, clay, $\mathrm{c}_{\mathrm{C} 0}=0.58 \mathrm{~g} / \mathrm{l}, \varepsilon_{\mathrm{V}}=40 \mathrm{~W} / \mathrm{m}^{3}, \mathrm{t}_{\mathrm{F}}=1-10 \mathrm{~min}, \mathrm{D}_{\mathrm{F}}$ $=0.26-3.04 \mathrm{ml} / 1$

deviations for the lowest concentration $0.44 \mathrm{~g} / \mathrm{l}$ can be seen mainly. We assume that these deviations are caused by a nonlinear relation between the turbidity and the pollution concentration. Based on this hypothesis we introduced the correction based on the Lambert-Beer law. After this correction the nonlinear dependence of the turbidity vs. pollutant concentration is respected which is reflected in the excellent tightness of the measured and predicted data as seen in Fig. 12. The final results are prepared for publication.

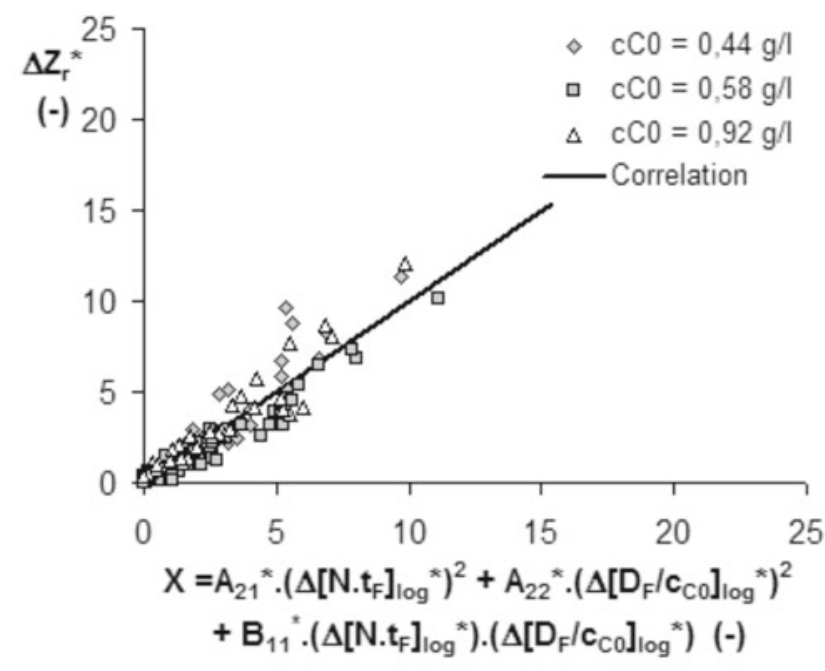

Figure 12. Experimental data vs. correlation (12) $\Delta Z_{r}^{*}=f(\Delta[N$. $\left.\left.\mathrm{t}_{\mathrm{F}}\right]^{*}{ }_{\log }, \Delta\left[\mathrm{D}_{\mathrm{F}} / \mathrm{c}_{\mathrm{C} 0}\right]_{\log }{ }^{*}\right)$ - data Šulc and Ditl ${ }^{5}$ - after correction

\section{Scale up}

Camp $^{7}$ proposed as the main design parameters the average velocity gradient $\mathrm{G}$ and the product of velocity gradient and time, referred to as the Camp number, for which the flocculation performance should be the same, regardless of the tank size or impeller type. As mentioned above, although this approach has been discussed and criticized by many authors, it is still used in industrial practice for design and control. Oldshue and $\mathrm{Mady}^{21}$ investigated the effect of impeller speed on residual turbidity in two tanks $460 \mathrm{~mm}$ and $760 \mathrm{~mm}$ in 
diameter stirred by a Rushton turbine and an A212 axial impeller. The flocs were separated by sedimentation. The average velocity gradient $G$, the flocculation time and the settling time were kept the same in both tanks. Ducoste and Clark $^{22}$ investigated the effect of the impeller type and tank size on the flocculation process in three tanks $5 \mathrm{~L}, 28 \mathrm{~L}$ and $560 \mathrm{~L}$ in volume stirred by a Rushton turbine and an A 310 axial impeller. The experiments were carried out at a constant average velocity gradient and at a constant flocculation time in all three tanks. After flocculation, the sample was withdrawn and the final particle size distribution was determined. Both of these studies found that the flocculation performance decreases with the increasing scale.

Since flocculation is a very complex process consisting of many mechanisms affected by a wide range of variables, the scale-up criteria for each phenomenon need to be formulated, i.e. a multidimensional approach must be applied instead of the one-dimensional approach that has been used to date. If the scale-up criteria for all mechanisms are fulfilled, the same flocculation results might be expected. Among the participating mechanisms, we consider the following to be important for flocculation performance, so that their scale-up criteria need to be formulated: mixing, flocculation time, chemical environment and floc separation. On the basis of these findings, we proposed ${ }^{\mathbf{2 3}}$ the following scale up rules:

$-\mathrm{P} / \mathrm{V}=$ const. - the same specific power input into a tank $D_{2}$ in diameter as the specific power input into a tank $\mathrm{D}_{1}$ in diameter to provide the same average mixing intensity.

$-\mathrm{t}_{\mathrm{F}}{ }^{*}=$ N.t $\mathrm{t}_{\mathrm{F}}=$ const. - the same dimensionless flocculation time in tank $\mathrm{D}_{2}$ in diameter as the dimensionless flocculation time in the tank $\mathrm{D}_{1}$ in diameter to provide the same number of passages of flocs through the impeller region.

$-\mathrm{D}_{\mathrm{F}}=$ const. - the same flocculant dosage in the tank $\mathrm{D}_{2}$ in diameter as the flocculant dosage in the tank $\mathrm{D}_{1}$ in diameter for a given flocculant type and wastewater quality to provide the same chemical environment.

Since the flocs will be separated by sedimentation, the sedimentation time was set up on the basis of the condition $\mathrm{u}_{\text {sed }}=$ const. - the same sedimentation velocity in the tank $\mathrm{D}_{2}$ in diameter as the sedimentation velocity in the $D_{1}$ tank in diameter to provide floc removal of same size. The same flocculation results were achieved fulfilling these conditions.

The scale-up criteria proposed here were tested in three baffled tanks $0.15 \mathrm{~m}-, 0.20 \mathrm{~m}$ - and $0.30 \mathrm{~m}$ in diameter agitated by a Rushton turbine. Clay slurry was used as a model wastewater. The experiments were carried out at the mixing intensity $40 \mathrm{~W} / \mathrm{m}^{3}$ and clay concentration $0.58 \mathrm{~g} / \mathrm{l}$. The model wastewater was flocculated using the organic flocculant Sokoflok 16A (solution 0.1 wt. $\%$ ), flocculant dosage $\mathrm{D}_{\mathrm{F}}=2.48 \mathrm{ml} / \mathrm{l}$. The flocs were separated by sedimentation. The experimental data are presented in Fig. 13. It was found that the course of the flocculation for vessels $0.20 \mathrm{~m}$ and $0.30 \mathrm{~m}$ in diameter was practically the same. For the vessel of diameter D $=0.15 \mathrm{~m}$, the degree of turbidity removal was slightly lower, probably due to somewhat different hydrodynamic conditions in the impeller zone. A comparison of the experimental data and the generalized correlation (2) is depicted in Fig. 14. The effect of the vessel size on the generalized correlation parameters was investigated statistically by hypothesis testing. According to the results of the test, all correlation parameters can be statistically taken as constant and independent of the vessel size. The maximum turbidity removal degree $\mathrm{Z}_{\mathrm{e} \text { max }}{ }^{*}=$ $96.4 \pm 1 \%$ was found for the dimensionless flocculation time $1582 \pm 230$.

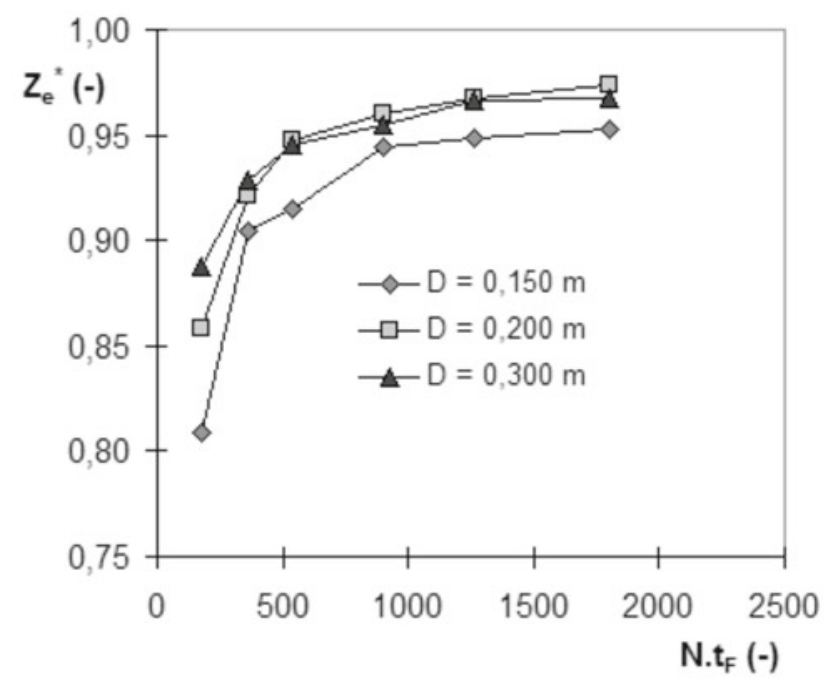

Figure 13. Experimental data $Z_{r}^{*}=f\left(N . t_{F}\right)$ for $D_{F}=$ const. - Sulc and Ditl ${ }^{23}$, clay, $\mathrm{c}_{\mathrm{C} 0}=0.58 \mathrm{~g} / \mathrm{l}, \varepsilon_{\mathrm{V}}=40 \mathrm{~W} /$ $\mathrm{m}^{3}, \mathrm{D}_{\mathrm{F}}=2.48 \mathrm{ml} / \mathrm{l}$

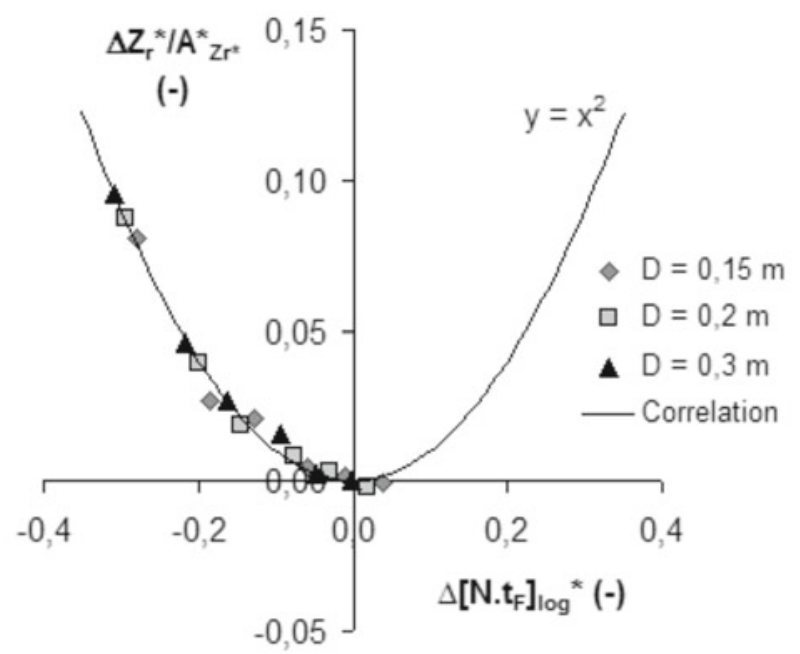

Figure 14. Experimental data vs. correlation (2) $\Delta \mathrm{Z}_{\mathrm{r}}^{*}=\mathrm{f}$ $\left(\Delta\left[\mathrm{Nt}_{\mathrm{F}}\right]^{*}{ }_{\log }\right)$ for $\mathrm{D}_{\mathrm{F}}=$ const. - Sulc and Ditl ${ }^{23}$, clay, $\mathrm{c}_{\mathrm{C} 0}=0.58 \mathrm{~g} / \mathrm{l}, \varepsilon_{\mathrm{V}}=40 \mathrm{~W} / \mathrm{m}^{3}, \mathrm{D}_{\mathrm{F}}=2.48 \mathrm{ml} / \mathrm{l}$

\section{CONCLUSIONS}

This paper has summarized our results obtained in the course of a long-term research on flocculation. The effect of flocculation time, flocculant dosage, impurity concentration, mixing intensity and the tank size on flocculation performance was experimentally studied in a mechanically agitated vessel. The macroscopic approach was applied for flocculation modelling.

The simple semiempirical generalized correlation ${ }^{4}$ for flocculation kinetics and the simple semiempirical generalized correlation ${ }^{5}$ quantifying the effect of flocculation time and flocculant dosage on flocculation were used for data treatment. Our model and the proposed 
data treatment is applicable for different systems and it enables for each system turbidity removal degree prediction, determination of dependence of flocculant dosage $D_{F}$ on flocculation time $t_{F}$ for the desired flocculation efficiency and scale-up for a particular system. The adjustable model parameters should be determined for each system separately.

The proposed generalized correlation for flocculation kinetics was extended up to flocculation induced by a static mixer. The proposed model was successfully tested on data of Suharyono and Hogg ${ }^{19}$.

The experimental results obtained for the proposed scale up rules ${ }^{23}$ have been presented. When the proposed scale-up rules were applied, the flocculation course for vessels $0.20 \mathrm{~m}$ and $0.30 \mathrm{~m}$ in diameter were found to be practically the same. For $\mathrm{D}=0.15 \mathrm{~m}$, the efficiency is slightly lower, probably due to various hydrodynamic conditions in the impeller region.

\section{Acknowledgment}

This research has been supported by MŠMT of the Czech Republic - Research Project MSM6840770035.

\begin{tabular}{|c|c|}
\hline Symbols & \\
\hline $\mathrm{A}_{\mathrm{Zr}^{*}}^{*}$ & $\begin{array}{l}\text { residual turbidity shift coefficient; model } \\
\text { parameter (2) }\end{array}$ \\
\hline $\mathrm{A}_{\mathrm{Zr}^{*}(\mathrm{D})}^{*}$ & $\begin{array}{l}\text { residual turbidity shift coefficient; model } \\
\text { parameter (9) }\end{array}$ \\
\hline $\mathrm{A}_{12}{ }^{*}$ & $\begin{array}{l}\text { generalized correlation parameter; model } \\
\text { parameter (12) }\end{array}$ \\
\hline $\mathrm{A}_{22}{ }^{*}$ & $\begin{array}{l}\text { generalized correlation parameter; model } \\
\text { parameter (12) }\end{array}$ \\
\hline $\mathrm{B}_{11}{ }^{*}$ & $\begin{array}{l}\text { generalized correlation parameter; model } \\
\text { parameter (12) }\end{array}$ \\
\hline $\mathrm{c}_{\mathrm{p} 0}$ & initial solid pollutant concentration, $\mathrm{g} / \mathrm{l}$ \\
\hline $\mathrm{D}$ & tank diameter, $\mathrm{m}$ \\
\hline $\mathrm{D}_{\mathrm{F}}$ & flocculant dosage, $\mathrm{ml} / \mathrm{l}, \mathrm{mg} / \mathrm{l}$ \\
\hline $\mathrm{D}_{\mathrm{Fmin}}$ & $\begin{array}{l}\text { generalized correlation parameter; model } \\
\text { parameter }(9), \mathrm{ml} / \mathrm{l}, \mathrm{mg} / \mathrm{l}\end{array}$ \\
\hline$\left[\mathrm{D}_{\mathrm{F}} / \mathrm{c}_{\mathrm{p} 0}\right]_{\mathrm{max}}$ & $\begin{array}{l}\text { generalized correlation parameter; model } \\
\text { parameter }(22)\end{array}$ \\
\hline$\left[\mathrm{D}_{\mathrm{F}} / \mathrm{c}_{\mathrm{p} 0}\right]_{\min }$ & $\begin{array}{l}\text { generalized correlation parameter; model } \\
\text { parameter (12) }\end{array}$ \\
\hline G & $\begin{array}{l}\text { velocity } \\
(\mathrm{P} /(\mathrm{V} \cdot \mu))^{1 / 2} \\
\mathrm{~s}^{-1}\end{array}$ \\
\hline G.t $t_{F}$ & Camp number \\
\hline$i_{S}$ & number of static mixer elements \\
\hline & static mixer length, $\mathrm{m}$ \\
\hline & length of static mixer element, $\mathrm{m}$ \\
\hline & ational speed, rpm \\
\hline$\left[\mathrm{N} . \mathrm{t}_{\mathrm{F}}\right]_{\min }$ & neter (2), (12) \\
\hline $\mathrm{P}$ & impeller power input, $\mathrm{W}$ \\
\hline $\mathrm{t}_{\mathrm{F}_{*}}$ & flocculation time, minute \\
\hline $\mathrm{t}_{\mathrm{F}}{ }^{*}$ & dimensionless flocculation time \\
\hline $\mathrm{V}$ & tank volume, $\mathrm{m}^{3}$ \\
\hline $\mathrm{Z}_{0}$ & turbidity before flocculation, FAU \\
\hline $\mathrm{Z}_{\mathrm{r}}$ & residual turbidity after flocculation, FAU \\
\hline $\mathrm{Z}_{\mathrm{e}}^{*}$ & turbidity removal degree \\
\hline $\mathrm{Z}_{\mathrm{r}}^{*}$ & residual turbidity degree \\
\hline $\mathrm{Z}_{\mathrm{r} \text { min }}^{*}$ & model parameter (2), (6) \\
\hline & model parameter $(9)$ \\
\hline $\mathrm{Z}_{\mathrm{r} \min (\mathrm{t}, \mathrm{D})}^{*}$ & model parameter (12) \\
\hline
\end{tabular}

\section{Greek letters}

$\Delta\left[\mathrm{D}_{\mathrm{F}}\right]^{*}{ }_{\log } \quad$ variable

$\Delta\left[\mathrm{D}_{\mathrm{F}} / \mathrm{c}_{\mathrm{p} 0}\right]^{*}{ }_{\log }$ variable

$\Delta\left[\mathrm{i}_{\mathrm{S}}\right]^{*}{ }_{\log }$ variable

$\Delta\left[\mathrm{N} \cdot \mathrm{t}_{\mathrm{F}}\right]^{*}{ }^{*}$ log variable

$\Delta \mathrm{Z}_{\mathrm{r}}^{*} \quad$ variable

$\varepsilon_{\mathrm{V}} \quad$ specific impeller power input (per volume unit); $\varepsilon_{\mathrm{V}}=\mathrm{P} / \mathrm{V}, \mathrm{W} / \mathrm{m}^{3}$

\section{LITERATURE CITED}

1. Thomas, D.N., Judd, S.J. \& Fawcett, N. (1999). Flocculation modelling: a review. Water Res. 33(7), 1579-1592. DOI: 10.1016/S0043-1354(98)00392-3.

2. von Smoluchowski, M. (1917). Versuch einer mathematischen theorie der koagulations - kinetics kolloid lösungen. Z.Phys. Chem. 92, 129-168.

3. Šlc, R. \& Ditl, P. (2008). The effect of flocculent dosage onto flocculation kinetics. Czasopismo Techniczne - Seria: MECHANIKA 105(2), 341-349.

4. Sulc, R. (2003). Flocculation in a turbulent stirred vessel. Ph.D. Thesis, Czech Technical University in Prague, Prague, Czech Republic.

5. Šulc, R. \& Ditl, P. (2007). Flocculation of clay slurry in a vessel agitated by Rushton turbine: effect of clay concentration at mixing intensity $40 \mathrm{~W} / \mathrm{m}^{3}$. In $34^{\text {th }}$ International Conference of the Slovak Society of Chemical Engineering SSCHE 2007, 21-25 May 2007. Tatranske Matliare, Slovak Republic: Slovak Society of Chemical Engineering.

6. Bernhardt, H. \& Schell, H. (1993). Effects of energy input during orthokinetic aggregation on the filterability of generated flocs. Water Sci. Technol. 27(10), 35-65.

7. Camp, T.R. (1955). Flocculation and flocculation basins. Trans. ASCE 120(1), 1-16.

8. Ives, K.J. (1968). Theory and operation of sludge blanket clarifiers. Proc. Inst. Civ. Eng. 39(2), 243-260.

9. Argaman, Y. \& Kaufman W.J. (1970). Turbulence and flocculation. J. Sanit. Eng. Div. ASCE. 96(2), 223-241.

10. Lai, R.J. (1975). Physical aspects of mixing in coagulation control. PhD. thesis (part), University of Florida, USA.

11. Cleasby, J.L. (1984). Is velocity gradient a valid turbulent flocculation parameter? J. Environ. Eng. ASCE, 110(5), 875-897. DOI: 10.1061/(ASCE)0733-9372(1984)110:5(875)

12. Clark, M.M. (1985). Critique of Camp and Stein's RMS velocity gradient. J. Environ. Eng. ASCE 111(6), 741-754. DOI: 10.1061/(ASCE)0733-9372(1985)111:6(741)).

13. Lee, S.I., Seo, I.S. \& Koopman, B. (1994). Effect of mean velocity gradient and mixing time on particle removal in seawater induced flocculation. Water Air Soil Poll. 78(1-2), 179-188. DOI: 10.1007/BF00475676.

14. Lin, S.D. \& Lee C.C. (2001). Water and wastewater calculations manual. USA: McGraw Hill. ISBN 978-0071371957

15. Weiner, R.F. \& Matthews, R. (2003). Environmental Engineering ( $4^{\text {th }}$ ed.) Boston, USA: Butterworth, Heinemann. ISBN 978-0080494777

16. Bache, D.H. \& Gregory, R. (2007). Flocs in water treatment. London, UK: IWA Publishing. ISBN: 978-1843390633

17. Šulc, R. \& Ditl, P. (2002). Effect of Mixing and Flocculation Time onto Flocculation Kinetics and Flocculant Dosage - Rushton turbine. In $15^{\text {th }}$ International Congress of Chemical and Process Engineering CHISA 2002, 25-29 August 2002. Prague, Czech Republic: Czech Society of Chemical Engineering 18. Sulc, R. \& Ditl, P. (2003). Model kinetiky flokulace ve statickém směšovači - studie. In $7^{\text {th }}$ International Scientific Conference Mechanical Engineering, 5-6 November 2003 (pp. 1-6). Bratislava, Slovak Republic: Slovak University of Technology.

19. Suharyono, H. \& Hogg, R. (1996). Flocculation in flow through pipes and in-line mixers. Miner. Metall. Proc. 13, 93-97. 
20. Šulc, R. \& Ditl, P. (2004). Vliv dávky flokulantu na flokulaci - návrh a ověření generalizované korelace. In $8^{\text {th }}$ International Scientific Conference Mechanical Engineering, September 2004. Bratislava, Slovak Republic: Slovak University of Technology.

21. Oldshue, J.Y. \& Mady, O.B. (1978). Flocculation performance of mixing impellers. Chem. Eng. Prog. 74, 103-108.

22. Ducoste, J.J. \& Clark, M.M. (1998). The influence of tank size and impeller geometry on turbulent flocculation: I. Experimental. Environ. Eng. Sci. 15(3), 215-224. DOI: 10.1089/ ees.1998.15.215.

23. Šulc, R. \& Ditl P. (2009). Scale up of clay slurry flocculation in an agitated tank. Chemical and Process Engineering (Inżynieria chemiczna i procesowa) 30(3), 443-451. 